\title{
PLURALISME HUKUM DAN URGENSI KAJIAN SOCIO-LEGAL MENUJU STUDI DAN PENGEMBANGAN HUKUM YANG BERKEADILAN SOSIAL
}

\author{
Joeni Arianto Kurniawan \\ Fakultas Hukum Universitas Airlangga, joeniarianto@gmail.com
}

\begin{abstract}
:
'Justice', philosophically, is classified into two; legal justice and social justice. Legal justice refers to justice based on the parameters of the rules while social justice may be defined as equality arises from human relation in the existing social structure. Referring to the implementation of the law nowadays, it is likely that justice cannot be achieved by looking only at the legal justice. Providing justice should also count on the aspect of social justice. Most of the time, the problem of social justice is related to the access to justice. It is so because the existing law is unable to serve legal justice via its rules only. In other words, it is undoubtful that the justice is not merely legal problem but also a social problem. Therefore, jurisprudence should expand its doctrinal and normative approach to socio-legal approach. This article analyse the urge and the contribution of social-legal approach as interdisciplinary study which connect normatf aspect of jurisprudence with social study. Aiming to create a study which is able to provide equality access and justice for all, this article takes legal pluralism concept as the entry point.
\end{abstract}

Keywords; Legal-pluralism, legal-study, social justice

\begin{abstract}
Abstrak:
Keadilan secara filosofis bisa dikelompokkan menjadi dua macam, yakni keadilan hukum (legal justice) dan keadilan sosial (social justice). Keadilan hukum bisa dimaknai sebagai keadilan menurut aturan hukum yang ada, sedangkan keadilan sosial bisa dimaknai sebagai kesetaraan antara manusia dengan manusia yang lain berkait dengan struktur sosial yang ada. Merujuk pada praktek pengembanan hukum yang ada, pencapaian keadilan tidak cukup jika hanya didasarkan pada keadilan hukum semata melainkan juga harus memperhatikan aspek keadilan sosial. Hal ini dikarenakan aspek keadilan sosial berkaitan dengan persoalan akses kepada hukum dan keadilan (access to justice) yang dideterminasi oleh struktur sosial yang ada, yang justru seringkali tidak diatur oleh aturan hukum dengan legal justice-nya. Berdasarkan fakta ini, maka jika memang salah satu tujuan hukum adalah untuk mencapai keadilan, proses penelaahan hukum mutlak tidak bisa lagi secara positivistik ala Kelsenian yang mengisolir kajian (ilmu) hukum hanya secara doktrinal-normatif berdasarkan aturan hukum apa adanya, melainkan harus diperluas spektrumnya juga pada kajian sosial di luar ilmu hukum an sich karena persoalan keadilan sosial adalah persoalan sosial. Tulisan ini mengulas urgensi dan
\end{abstract}


kontribusi kajian socio-legal, sebagai kajian interdisipliner yang menghubungkan kajian hukum positif (kajian hukum secara doktirnal normatif) dan kajian sosial, dalam rangka menciptakan kajian hukum yang berwawasan social justice sekaligus yang mendorong terbukanya kesetaraan akses kepada hukum dan keadilan bagi masyarakat luas, dengan mengambil contoh pada kajian pluralisme hukum sebagai derivasi dari kajian socio-legal dalam rangka mencapai tujuan tersebut di atas.

Kata-kata kunci: Pluralisme hukum, kajian hukum, keadilan sosial.

\section{Pendahuluan}

Law may regulate people equally, but people are not equal structurally (hukum mungkin mengatur masyarakat secara sama, tetapi masyarakat tidaklah setara secara struktural). Itulah fakta dalam realitas sosioyuridis $^{1}$ yang ada di berbagai kehidupan masyarakat di dunia ini, khususnya di negara dunia ke tiga seperti Indonesia di mana masih banyak terjadi kesenjangan sosial yang kerapkali terasa begitu memprihatinkan.

Merujuk langsung pada konteks realaitas hukum di Indonesia, secara normatif prinsip equality before the law atau persamaan di muka hukum secara eksplisit diatur di dalam UUD 1945 sebagai konstitusi negara ini, yakni di pasal 27 ayat 1 yang berbunyi:

"Segala warga negara bersamaan kedudukannya di dalam hukum dan pemerintahan dan wajib menjunjung hukum dan pemerintahan itu dengan tidak ada kecualinya."

Namun, walau konstitusi telah mengatur secara tegas prinsip persamaan di muka hukum tersebut, pada faktanya masih juga banyak persoalan keadilan yang tidak bisa diselesaikan oleh hukum

${ }^{1}$ Istilah "realitas sosio-yuridis" di sini penulis gunakan sebagai istilah yang bermakna realitas hukum dalam konteks sosial yang ada. sendiri yang berpangkal pada fakta adanya stratifikasi sosial dalam masyarakat. Ambil saja contoh fakta kontras yang pernah menjadi sorotan masyarakat seperti halnya perbandingan antara kasus pencurian sandal jepit oleh seorang pelajar di Palu, Sulawesi Tengah, atau kasus pencurian kakao oleh nenek Minah di Banyumas yang telah divonis pidana penjara selama 1,5 tahun, dengan kasus korupsi yang marak terjadi di negeri ini, sebagaimana yang disorot oleh harian Kompas dalam artikel yang berjudul "Kejamnya Keadilan 'Sandal Jepit".. ${ }^{2}$ Berdasarkan apa yang diulas dalam artikel di harian Kompas tersebut maka kita akan dapat merasakan betapa hukum jika berhadapan dengan masyarakat yang berasal dari golongan tidak berpunya, sebagaimana terwakili oleh si pencuri sandal dan kakao, akan terlihat begitu perkasa. Tetapi, hukum akan cenderung berubah menjadi "lembek" ketika ia berhadapan dengan si penguasa, yakni orang yang memiliki kekuatan berbagai sumber daya, seperti halnya yang terjadi pada kasus-kasus korupsi yang dilakukan oleh para elit dengan hukuman yang tidak jauh berbeda dengan si pencuri sandal dan kakao tadi, yakni berdasarkan data ICW untuk kasus korupsi di tahun 2010 mayoritas perkara $(60,68 \%)$ divonis pidana

${ }^{2}$ Kompas, edisi 6 Januari 2012, tersedia di: http:// nasional.kompas.com/read/2012/01/06/09445281/ Kejamnya.Keadilan.Sandal.Jepit. 
penjara antara 1-2 tahun saja. ${ }^{3}$

Hal yang paling krusial dalam persoalan di atas adalah bahwa secara yuridis-normatif tidak ada yang salah dengan proses hukum baik yang dilakukan kepada si pencuri sandal dan kakao serta pada para koruptor tersebut karena semua dilakuakn tanpa menyalahi ketentuan undang-undang. Walau begitu, tetap saja persoalan tersebut dirasa telah mencederai rasa keadilan masyarakat. Ini menunjukkan adanya ketidak sebangunan antara keadilan hukum sebagaimana diatur di dalam aturan hukum yang ada yang dijadikan landasan para aparat penegak hukum dalam memproses secara yuridis kasus-kasus tersebut dengan ukuran keadilan substantif sebagaimana diharapkan oleh masyarakat. Salah satu pangkal dari persoalan tersebut adalah adanya perbedaan kemampuan akses menuju keadilan.

Jika seorang koruptor mampu mendapatkan vonis yang ringan dari hakim, merujuk pada data ICW di atas, maka hal itu dikarenakan mereka, yang secara fakta selalu cenderung berasal dari kelas sosial yang mampu secara ekonomi, memiliki sumber daya yang cukup untuk menyewa pengacara yang handal sehinggga bisa meyakinkan hakim untuk tidak memidana si pelaku korupsi dengan pidana yang berat. Di samping itu, mereka juga memiliki sumber daya yang berlebih sehingga bisa mengajukan upaya penangguhan penahanan sehingga tidak perlu menjalani penahanan dalam ruang tahanan yang sempit dan pengap selama kasus yang mendera mereka sedang dalam proses hukum hingga mendapatkan

\footnotetext{
${ }^{3}$ Ibid.
}

putusan yang berkekuatan hukum tetap. Mereka juga mampu untuk mengajukan upaya hukum hingga ke tingkat akhir sekalipun jika sekiranya putusan hakim tidak berpihak pada keinginan mereka. Mereka-mereka yang berada dalam kelas sosial yang kuat secara sumber daya ini juga bisa dipastikan memiliki taraf pendidikan yang cukup tinggi, sehingga memiliki tingkat intelektualitas yang memadahi untuk mencari celah-celah hukum yang mungkin ada yang bisa digunakan untuk mendapatkan keuntungan dari situ.

Hal yang sama tentu tidak akan terjadi untuk kasus si pencuri sandal dan nenek Minah. Mereka adalah masyarakat yang tergolong dalam kelas sosial yang lemah secara sumber daya sehingga secara logis memiliki kemampuan yang sangat terbatas untuk mendayagunakan hak-hak yang mereka miliki jika mereka memiliki persoalan hukum. Masyarakat seperti ini tentu saja tidak akan mampu membayar pengacarahandalnanmahalsehinggamereka bisa memiliki peluang untuk mendapatkan putusan bebas. Seperti halnya yang terjadi pada nenek Minah, untuk bisa datang ke persidangan atas dirinya saja ia harus mencari uang pinjaman sebesar Rp. 30.000,untuk biaya transportasi ke Pengadilan yang berjarak jauh dari rumahnya. ${ }^{4}$ Orang-orang seperti ini seringkali juga memiliki taraf pendidikan yang rendah sehingga adalah sangat logis jika kemudian mereka menjadi buta hukum dan sekaligus buta akan hakhak mereka yang dilindungi oleh hukum.

${ }^{4}$ Ibid. 
Berdasarkan uraian di atas, terlihat bahwa keadilan menurut aturan hukum atau yang biasa disebut secara singkat sebagai keadilan hukum (legal justice) tidak selalu sebangun dengan keadilan dalam hal kesetaraan masyarakat dalam struktur sosialnya untuk mendapatkan akses perlindungan dari pranata-pranata sosial yang ada, termasuk perlindungan hukum. Jenis keadilan yang kedua inilah yang sering disebut dengan istilah keadilan sosial (social justice).

Merujuk pada konteks sistem hukum yang diterapkan di Indonesia saat ini, kajian hukum yang ada masih dirasakan sulit untuk diarahkan hingga mencakup isu keadilan sosial. Hal ini disebabkan karena kajian hukum yang ada masih sangat terwarnai dengan paradigma positivisme hukum yang memang bisa dikatakan merupakan landasan filsafat hukum dari Civil Law System sebagai sistem hukum yang diwarisi oleh negeri ini dari bangsa Belanda pada masa kolonialisme yang terus digunakan hingga kini.

Isu inilah yang akan diulas dalam tulisan ini, yakni mengenai apa dan mengapa kajian hukum nan konservatif di Indonesia, yang begitu dipengaruhi oleh paradigma positivisme hukum, adalah kajian yang berjarak dengan isu social justice, serta alternatif apa yang bisa diupayakan dalam rangka mengembangkan suatu kajian hukum yang mampu mencakup isu-isu social justice sehingga nantinya diharapkan dapat mendorong praktek pengembanan hukum yang tidak saja diarahkan pada tujuan untuk memenuhi tuntutan keadilan hukum tetapi juga keadilan secara sosial.

Namun, sebelum menginjak poin utama tulisan ini sebagaimana disinggung di atas, terlebih dahulu akan diuraikan secara singkat mengenai apa itu konsep social justice (keadilan sosial) sesungguhnya, yakni pada bab di bawah ini.

\section{Konsep Social Justice}

Istilah social justice atau keadilan sosial sesungguhnya bukanlah istilah yang asing dalam tata hukum Indonesia, mengingat istilah ini secara eksplitisit disebutkan dalam fundamen sumber hukum Indonesia, baik itu adalah Pancasila yakni Sila V yang berbunyi: "Keadilan Sosial bagi Seluruh Rakyat Indonesia," maupun dalam naskah Pembukaan UUD 1945 alienia ke-4 yang menyebutkan:

"Kemudian dari pada itu untuk membentuk suatu Pemerintahan Negara Republik Indonesia yang melindungi segenap bangsa Indonesia dan seluruh tumpah darah Indonesia dan untuk memajukan kesejahteraan umum, mencerdaskan kehidupan bangsa, dan ikut melaksanakan ketertiban dunia yang berdasarkan kemerdekaan, perdamaian abadi, dan keadilan sosial, maka disusunlah Kemerdekaan Kebangsaan Indonesia itu dalam suatu Undang-Undang Dasar Negara Indonesia, yang terbentuk dalam suatu susunan Negara Republik Indonesia yang berkedaulatan rakyat dengan berdasarkan kepada Ketuhanan Yang Maha Esa, Kemanusiaan Yang 
Adil dan Beradab, Persatuan Indonesia dan Kerakyatan yang Dipimpin oleh Hikmat Kebijaksanaan dalam Permusyawaratan / Perwakilan, serta dengan mewujudkan suatu Keadilan Sosial bagi seluruh rakyat Indonesia.

Namun, walaupun disebutkan secara tegas dalam naskah dua fundamen sumber hukum Indonesia di atas, tidak ada suatu rumusan normatif apapun dalam berbagai aturan hukum di Indonesia yang menjelaskan secara konseptual tentang makna istilah keadilan sosial ini. Untuk itu, guna menemukan penjelasan konseptual atas istilah ini, maka harus dirujuk beberapa literatur yang secara khusus mengelaborasi diskursus social justice.

Menurut Nancy Fraser, dalam perkembangan dunia saat ini, klaim atas socialjustice terbagi ke dalam dua kelompok, yakni yang pertama dan sekaligus yang utama adalah politik redistribusi (politics of redistribution) yakni suatu politik yang menghendaki adanya distribusi sumber daya (ekonomi) dan kesejahtreraan secara lebih adil dan kedua adalah politik pengakuan (politics of recognition) yakni politik yang menghendaki adanya pengakuan atas perspektif yang berbeda berkaitan latar belakang etnis, ras, seksualitas, dan gender. ${ }^{5}$

Masih menurut Fraser, konsep (politik) redistribusi berasal dari tradisi liberal khususnya yang muncul di negara-negara

\footnotetext{
5 Nancy Fraser, "Social Justice in the Age of Identity Politics: Redistribution, Recognition, and Participation" dalam Nancy Fraser dan Axel Honneth, "Redistribution or Recognition? A Political-Philosophical Exchange", Verso, London-New York, 2003, h. 7.
}

Anglo-Amerika pada akhir abad ke-20 yang mencoba mensintesiskan antara kebebasan individu pada satu sisi dan prinsip egalitarian dalam demokrasi sosial (social-democracy). ${ }^{6} \quad$ Sedangkan istilah recognition (pengakuan) berasal dari tradisi filsafat Hegelian khususnya mengenai fenomenologi kesadaran dimana konsep pengakuan ini menunjuk suatu hubungan timbal balik yang ideal antara subyek, di saat subyek memandang subyek lain secara setara dan sekaligus terpisah darinya. ${ }^{7}$

Lebih jauh lagi, Fraser dalam menjelaskan dua elemen pokok dalam prinisp social justice ini yakni politik redistribusi dan politik pengakuan, memaparkan bahwa persoalan redistribusi berkaitan dengan stratifikasi sosial yang berakar pada realitas struktur ekonomi dalam masyarakat sehingga ketidakadilan dalam perspektif ini adalah adanya suatu maldistribusi sosio-ekonomi dan oleh karena itu ketidakadilan ini ditanggulangi melalui praktek redistribusi yang memperbaiki distribusi hak dan kewajiban, khususnya penguasaan sumber daya ekonomi dalam kelas-kelas sosial sehingga tidak ada lagi praktek yang sifatnya eksploitatif atas diri manusia. ${ }^{8}$ Sedangkan masalah recognition atau pengakuan adalah berkaitan dengan persoalan status kedirian seseorang dalam masyarakat yang terkait dengan kodekode budaya, di mana suatu ketidak adilan struktural dalam perspektif ini adalah diskriminasi terhadap sekolompok orang atas dasar status kultural yang dimilikinya,

\footnotetext{
${ }^{6}$ Ibid, h. 10.

${ }^{7}$ Ibid.

${ }^{8}$ Ibid, h. 16-17.
} 
dan munculnya ketidakadilan ekonomi adalah hasil dari diskriminasi ini. ${ }^{9}$

David Boucher dan Paul Kelly yang bertindak sebagai editor buku "Social Justice. From Hume to Walzer" menjelaskan bahwa istilah social justice adalah istilah yang berpadu-padan dengan istilah distributive justice (keadilan distributif), yakni keadilan menyangkut distribusi keuntungan yang muncul dari setiap kerja sama atau hubungan sosial yang terbentuk dalam masyarakat. ${ }^{10}$ Paradigma distributif adalah paradigma yang memandang bahwa persoalan ketidakadilan adalah persoalan yang muncul karena adanya monopoli sumber daya oleh sekelompok orang tertentu sehingga membuat kelompok masyarakat lain menjadi tidak memiliki akses atas sumber daya tersebut dan oleh karenannya membuat relasi antar kelompok ini menjadi tidak setara. ${ }^{11}$ Berkaitan dengan hal tersebut, social justice adalah dalam rangka untuk menghilangkan praktek monopoli ini. ${ }^{12}$

Salah satu eksponen yang bisa dirujuk sebagai penggagas keadilan distributif ini adalah para para penganut aliran British Idealism yang senada dengan Plato menekankan prinsip kesataraan dalam hal perolehan kesempatan. ${ }^{13}$ Menurutpandangan aliran ini, seseorang mungkin memiliki bakat yang tidak sama tetapi setiap orang harus memiliki kesempatan yang sama untuk mengembangkan bakat apapun yang mereka

\footnotetext{
9 Ibid, h. 17.

10 David Boucher and Paul Kelly, "Social Justice. From Hume to Walzer," Routledge, London-New York, 1998, h. 1.

11 Ibid, h. 10.

12 Ibid.

13 Ibid, h. 7.
}

miliki. ${ }^{14}$ Oleh karenanya, setiap orang harus didorong untuk mampu memperbaiki taraf kehidupannya dengan memberikan fasilitas dan kesempatan yang seluas-luasnya guna menunjang hal tersebut. ${ }^{15}$

Selain paradigma distributif, Boucher dan Kelly juga menunjukkan bahwa diskursus social justice juga melingkupi paradigma rekognisi dengan merujuk pada gagasan Michael Walzer yang menekankan bahwa persoalan ketidakadilan (juga) adalah menyangkut adanya fenomena dominasi suatu kelompok sosial atas kelompok sosial yang lain. ${ }^{16}$ Itulah mengapa menurut Walzer persoalan keadilan harus menggunakan pendekatan pluralisme dan demokrasi. ${ }^{17}$

Selain merujuk kepada Walzer, Boucher dan Kelly juga menjelaskan bahwa prinsip rokognisiatau pengakuaninijugamelingkupi gagasan yang diperjuangkan kaum feminis dan pembela hak-hak multikultural. ${ }^{18}$ Dengan merujuk pada Will Kymlicka sebagai salah satu eksponen penggagas diskursus pembelaan hak-hak multikultural, Boucher dan Kelly menunjukkan bahwa persoalan ketidakadilan adalah juga menyangkut penolakan pengembangan dan ekspresi identitas seseorang atau penolakan keikutsertaan seseorang ke dalam kultur dominan masyarakat akibat adanya latar belakang bahwa orang tersebut berasal dari kelompok etnis minoritas. ${ }^{19}$

\footnotetext{
14 Ibid.

15 Ibid.

16 Ibid, h. 10.

17 Ibid.

18 Ibid.

19 Ibid, h. 11.
} 
Berdasarkan semua uraian di atas, maka bisa dirangkum di sini bahwa konsep social justice atau keadilan sosial adalah suatu konsep keadilan menyangkut struktur masyarakat yang setara, sehingga tidak ada satu kelompok masyarakat yang lebih kuat dari kelompok yang lain, di mana ketidak setaraan itu bisa menyangkut akses terhadap sumber daya ekonomi dan kesejahteraan yang memerlukan politik (re)distribusi untuk menanggulanginya, dan juga menyangkut diskriminasi (perlakuan yang tidak setara) akibat adanya perbedaan identitas kultural sepertihalnya seksualitas, gender, etnisitas, dan semacamnya yang memerlukan politik rekognisi untuk menghilangkannya.

\section{Kajian Hukum dalam Tradisi Positivisme sebagai Kajian Hukum yang Asosial}

Berbicara mengenai kajian hukum di Indonesia, khususnya yang dilakukan di fakultas-fakultas hukum yang ada di negeri ini, maka kajian hukum tersebut pada hakekatnya adalah (sebatas) kajian hukum positif. Kajian sebagaimana demikian adalah kajian secara doktrinal atas aturan hukum positif yang ada yang bertujuan memberikan penguasaan atas prinsipprinsip yang dikandung dalam aturan hukum positif tersebut sehingga nantinya seorang yuris, sebagai sebutan bagi orang yang dianggap memiliki penguasaan atas suatu aturan hukum positif, diharapkan memiliki ketrampilan atau skill untuk menerapkan prinsip-prinsip hukum tersebut ke dalam kasus nyata. Konsep kajian hukum sebagaimana demikian adalah karena tujuan dari dilakukannya studi hukum di fakultas hukum adalah untuk mencetak apa yang disebut sebagai the legal professionals atau para praktisi hukum yang bekerja di sektorsektor yang memiliki kapasitas untuk menerapkan aturan hukum yang ada.

Adanya tradisi sebagaimana di atas sesungguhnya bisa dilacak dari akar kesejarahannya sebagai suatu warisan yang diturunkan dari apa yang dilakukan sejak masa kolonialisme Hindia Belanda. Sejarah didirikannya fakultas hukum sebagai lembaga pendidikan profesi hukum bisa dirujuk pangkalnya di tahun 1909, yakni saat didirikannya apa yang disebut sebagai Opleidingsschool voor de Indlandsche Rechtskundingen atau yang kemudian dikenal dengan istilah Rechtschool sebagai sekolah hukum yang dibuka bagi kaum pribumi untuk mempersiapkan mereka menjadi hakim Landraad..$^{20}$ Selanjutnya, apa yang disebutsebagai Rechtschool itu berubah menjadi Rechtshoogesschool dengan tujuan agar level pendidikan yang ada dalam Rechtschool tersebut ditingkatkan untuk menjadi setara dengan universitas, dan inilah yang kemudian menjadi cikal bakal fakultas hukum di Indonesia berikut kurikulum pendidikan hukumnya. ${ }^{21}$ Berdasarkan keadaan sebagaimana demikian, maka jelaslah terlihat bahwa kajian hukum yang ditradisikan dalam sistem pendidikan tinggi

${ }^{20}$ Soetandyo Wignjosoebroto, "Dari Hukum Kolonial ke Hukum Nasional. Dinamika SosioPolitik dalam Perkembangan Hukum di Indonesia,”. Raja Grafindo Persada. Jakarta, 1994, h. 153-154.

${ }^{21}$ Lihat: "Sejarah Singkat Fakultas Hukum Universitas Indonesia," Fakultas Hukum Universitas Indonesia, tersedia di:

http://law.ui.ac.id/index.php?option=com_conte nt $\&$ view $=$ article $\&$ id $=46 \&$ Itemid $=55$ 
hukum yang ada di Indonesia adalah kajian hukum praktis, sehingga keberadaannya tidak bisa dipisahkan dari sistem hukum yang diterapkan yang dalam kesejarahannya merupakan warisan dari tradisi sistem huku Belanda yang berakar pada sistem hukum Eropa Kontinental atau yang dikenal dengan nama Civil Law System.

Sebagaisistemhukumyangberkembang di hampir keseluruhan negara Eropa daratan sejak akhir abad ke-18, prinsip-prinsip yang ada dalam Civil Law System sangatlah dipengaruhi oleh gagasan-gagasan intelektual filosofis yang berkembang di sana pada waktu itu. ${ }^{22}$ Gagasan-gagasan tersebut adalah gagasan-gagasan yang begitu dipengaruhi oleh perkembangan pesat dari science yang mendorong adanya pandangan bahwa segala pengetahuan manusia, termasuk dalam bidang hukum, haruslah menggunakan metode layaknya yang ada dalam science. Hal ini bisa ditunjukkan dari pemikiran tokoh seperti Samuel Pufendorf dan Christopher Wolff dari Jerman yang menggagas suatu sistem hukum yang menggunakan metode saintifik ala Galileo dan Descartes, atau dengan kata lain mempromosikan hukum sebagai "science", yang dalam penerapannya dituangkan dalam pembentukan kitab perundangundangan yang berisikan prinsip-prinsip umum (norma hukum) untuk nantinya dideduksikan dan diujikan pada pengalaman (kasus nyata yang terjadi di masyarakat). ${ }^{23}$ Apa yang dikonsepkan oleh Pufendorf

${ }^{22}$ James G. Apple \& Robert P. Deyling, "A Primer on the Civil Law System," Federal Juducial Center of the United States, tanpa tahun, h. 12.

${ }^{23}$ Ibid, h. 13. dan Wolff tersebut dapat kita lihat sebagai semangat saintifikasi sosial, yakni semangat untuk menerapkan metode science ke dalam persoalan-persoalan sosial dikarenakan adanya kelebihan yang dimiliki oleh science yakni kemampuannya memberikan suatu hal yang obyektif dan bersifat pasti yang tidak dimiliki oleh epistimologi pengetahuan sebelumnya yang sepenuhnya hanya diderivasi dari doktrin agama yang bersifat metafisik dan oleh karenanya serba tidak pasti. Semangat inilah yang kemudian mengkristal dan menjadi basis suatu pandangan filosofis yang dinamakan sebagai positivisme, yakni suatu pandangan filsafat yang dikembangkan pertama kali oleh August Comte yang menekankan bahwa kebenaran hanya bisa dilandaskan pada halhal yang bersifat nyata dan pasti, dan oleh karenanya hal-hal yang bersifat metafisik ditolak. $^{24} \quad$ Sebagaimana yang sudah diawali oleh gagasan Pufendorf dan Wolff, yang masih digolongkan sebagai yuris yang beraliran naturalis-rasionalistis, semangat positivisme inipun kemudian juga menjalar ke bidang hukum dan menghasilkan apa yang disebut sebagai positivisme hukum. Bentuk lain dari aliran ini adalah apa yang disebut sebagai legisme, yakni aliran yang memaknai hukum hanya sebagai undangundang, sehingga tidak ada hukum di luar undang-undang. ${ }^{25}$ Itulah mengapa, prinsip dasar dari Civil Law System, sebagai sistem hukum yang sangat dipengaruhi oleh aliran ini, adalah bahwa sumber hukum yang

\footnotetext{
${ }^{24}$ Harun Hadiwijoyo, "Seri Sejarah Filsafat Barat 2," Kanisius, Yogyakarta, 1990, h. 109

${ }^{25}$ Lili Rasjidi dan Ira Thania Rasjini, "Dasar-Dasar Filsafat dan Teori Hukum," Citra Aditya Bakti, Bandung, 2004, h. 56.
} 
pertama dan utama adalah undang-undang (sebagai suatu aturan hukum positif yang tertulis). Selaras dengan prinsip yang ada dalam positivisme (yang menganggap metode science sebagai metode tunggal ilmu pengetahuan), positivisme hukum memandang sistem hukum sebagai suatu sistem yang logis, tetap, dan bersifat tertutup di mana keputusan-keputusan hukum yang benar / tepat dapat diperolah dengan alatalat logika dari peraturan-peraturan hukum yang telah ditentukan sebelumnya tanpa memperhatikan tujuan-tujuan sosial, politik, dan ukuran-ukuran moral. ${ }^{26}$

Berdasarkan sistem hukum dengan landasan filosofis sebagaimana demikian, maka tidaklah mengherankan jika kajian hukum positif adalah kajian hukum yang juga bersifat positivistik dalam artian membatasi kajiannya hanya sebatas pada tatanan norma-norma yang ada dalam suatu aturan hukum positif sebagaimana apa adanya. Hal ini selaras dengan apa yang dikonsepkan oleh Hans Kelsen, sebagai salah tokoh aliran positivisme hukum, ${ }^{27}$ melalui "Teori Murni tentang Hukum (Pure Theory of Law)"-nya yang terkenal itu. Merujuk pada teori Kelsen tersebut, kajian hukum (jurisprudence) dibatasi hanya pada pemaparan aturan hukum positif sebagaimana apa adanya dan bukan mengenai aturan hukum yang diidealkan. ${ }^{28}$ Sehingga, menurut Kelsen kajian hukum tidaklah mengikutsertakan elemen-elemen

26 Ibid, h. 58.

${ }^{27}$ Ibid, h. 60. Lihat juga: Soetandyo Wignjosoebroto, "Hukum: Paradigma, Metode, dan Dinamika Masalahnya," Elsam-Huma, Jakarta, 2002, h. 51-52.

${ }^{28}$ Hans Kelsen, "Pure Theory of Law," The Lawbook Exchange, Clark-New Jersey, 2005, h. 1. yang bukan hukum seperti halnya psikologi, sosiologi, etika, dan teori politik. ${ }^{29}$ Singkat kata, berdasarkan paradigma positivisme hukum ini, maka kajian hukum harus dibedakan secara tegas dari kajian sosial, dan oleh karenanya kajian sosial bukanlah bagian dari kajian hukum.

Merujuk kembali pada bab "Konsep Social Justice" di atas, maka kita bisa melihat bahwa konsep keadilan sosial atau social justice bukanlah sekedar konsep keadilan yang didasarkan pada aturan hukum semata. Alih-alih demikian, konsep social justice adalah konsep keadilan menyangkut kesetaraan relasi sosial secara struktural berkaitan penguasaan atas sumber daya ekonomi serta kemajemukan identitas budaya yang ada dalam masyarakat. Sehingga, isu keadilan sosial adalah isu yang lebih melihat pada realitas tentang bagaimana relasi-relasi sosial dalam masyarakat terkonstruksikan sebagai akibat dari penguasaan sumber daya ekonomi yang ada dan perlakuan atas mereka yang berbeda menurut identitas kulturalnya. Jika dikaitkan dengan konsep kajian hukum dalam paradigma positivisme hukum, maka akan jelas terlihat bahwa persoalanpersoalan keadilan sosial bukan menjadi isu bahasan dalam kajian hukum selama ia tidak diatur oleh aturan hukum positif yang ada. Sehingga, persoalan keadilan sosial cenderung menjadi persoalan yang berada di luar isu kajian hukum dan oleh karena itu kajian hukum secara positivistik menjadi cenderung mengisolasi diri dari konteks realita sosial yang ada.

${ }^{29}$ Ibid. 
Salah satu contoh nyata dari apa yang dipaparkan di atas adalah sebagaimana yang bisa didapati dari permasalahan berkait eksistensi masyarakat hukum adat di Indonesia, yang akan diulas dalam bab di bawah ini.

\section{Persoalan Eksistensi Masyarakat Hukum}

Adat: Urgensi Analisis Pluralisme Hukum dan Kajian Sosio-Legal sebagai Kajian Hukum nan Berkorelasi dengan

\section{Isu Keadilan Sosial}

Sebagai sebuah negara yang kaya akan kemajemukan, masyarakat di Indonesia adalah masyarakat yang hidup dalam begitu banyak ragam tradisi dan budaya, termasuk di antaranya adalah dalam hal tatanan organisasi sosial yang ada. Sejak pada masa penjajahan, masyarakat di nusantara ini dipaksa untuk tunduk ke dalam sebuah tatanan politik tunggal yang bernama Pemerintahan Kolonial Hindia Belanda. Begitu pula ketika bangsa ini memerdekakan dirinya dari kekuasaan kolonial, konsep tatanan politik yang dikenal sebagai negara bangsa (nation state) tersebut tetap dilanjutkan hingga melahirkan sebuah negara baru yang berstruktur negara kesatuan yang bernama Republik Indonesia. Berdasarkan konsep sebagaimana demikian, maka seluruh masyarakat di wilayah bekas kekuasaan Pemerintahan Kolonial Hindia Belanda disatukan di bawah satu otoritas negara, satu kekuasaan pemerintahan, dan satu hukum yang sama. ${ }^{30}$ Hanya saja, walaupun secara formal konsep tata

\footnotetext{
${ }^{30}$ Sebagaimana menjadi cirri-ciri dari konsep negara kesatuan. Lihat: Soehino, "Ilmu Negara," Penerbit Liberty, Yogyakarta, 1993, h. 224.
}

politik kenegaraan nan bersifat monolitik sebagaimana demikian yang diterapkan, hal tersebut tidak sepenuhnya diikuti oleh apa yang senyatanya dipraktekkan dalam kehidupan di masyarakat secara faktual. Walaupun secara formal telah terbentuk sebuah kekuasaan politik tunggal yang bernama Negara Kesatuan Republik Indonesia selama lebih dari 65 (enam puluh lima) tahun, tatanan kehidupan sosio-politik masyarakat di Indonesia dalam realitasnya tidak sepenuhnya mengikuti nalar politik formal tersebut. Hal ini dibuktikan dengan masih banyaknya terdapat kehidupan masyarakat di Indonesia yang secara sosio-politik mengorganisasikan dirinya ke dalam sebuah kesatuan hukum yang justru tidak didasarkan pada hukum positif negara, melainkan pada hukum adat yang mereka warisi secara tradisional dari nenek moyang mereka, yang kemudian dikenal dengan istilah persekutuan hukum adat (adatrechtsgemeenschap).

Persekutuan hukum adat, atau yang dalam bahasa konstitusi disebut sebagai kesatuan masyarakat hukum adat, ${ }^{31}$ adalah sebuah tatanan sosio-politik yang memiliki akar kesejarahan dan budaya yang sudah ada jauh sebelum konsep negara bangsa dengan hukum positifnya diimplementasikan di wilayah nusantara. Secara konseptual, merujuk pada apa yang diteorikan oleh Ter Haar, apa yang disebut sebagai adatrechtsgemeenschap atau persekutuan hukum adat ini dapat dimaknai sebagai masyarakat hukum dari golongan masyarakat Indonesia asli yang terikat dalam

\footnotetext{
${ }^{31}$ Pasal 18B ayat 2 UUD 1945.
} 
satu kesatuan secara lahir dan batin yang bertindak sebagai satu kesatuan organisasi menurut tingkah laku tertentu, di mana segala sesuatu dalam kesatuan masyarakat tersebut terjadi dan berlangsung akibat adanya suatu aturan tertentu yang tiada lain adalah aturan hukum adat. ${ }^{32}$ Selain apa yang dikonsepkan oleh Ter Haar di atas, Hazairin juga mengungkapkan bahwa masyarakatmasyarakat hukum adat seperti desa di Jawa, marga di Sumatra Selatan, nagari di Minangkabau, kuria di Tapanuli, wanua di Sulawesi Selatan, adalah kesatuan-kesatuan masyarakat yang mempunyai kelengkapankelengkapan untuk sanggup berdiri sendiri yang mempunyai kesatuan hukum, kesatuan penguasa, dan kesatuan lingkungan hidup berdasarkan hak bersama atas tanah dan air bagi semua anggotanya. ${ }^{33}$ Sehingga, dari uraian mengenai konsep persekutuan atau kesatuan masyarakat hukum adat di atas bisa dikatakan bahwa masyarakat hukum adat adalah suatu masyarakat hukum sebagai suatu institusi politik yang mandiri (mampu berdiri sendiri tanpa bergantung pada institusi sosial yang lebih besar) beserta segala macam perangkat kelembagaan yang ada yang pembentukan dan kehidupan di dalamnya didasarkan pada aturan hukum adat yang hidup dalam masyarakat tersebut. Oleh karena itu, kehidupan masyarakat hukum adat pada dasarnya tidak bertumpu pada keberadaan negara beserta kelengkapan hukum negaranya, melainkan bertumpu

\footnotetext{
32 Ter Haar, "Asas-Asas dan Susunan Hukum Adat," Pradnya Paramita, Jakarta, 1979, h. 27.

33 Rikardo Simarmata, "Pengakuan Hukum terhadap Masyarakat Adat di Indonesia," Regional Initiative on Indigenous Peoples' Rights and Development, UNDP, Jakarta, 2006, h. 36 .
}

pada aturan hukum adat mereka. Sehingga, setiap hak yang lahir dan eksis, baik itu hak kolektif maupun hak perseorangan, dalam suatu komunitas masyarakat adat disebabkan karena adanya aturan hukum adat dalam komunitas masyarakat tersebut. ${ }^{34}$

Sedangkan mengenai eksistensi hukum adat sebagai aturan hukum yang mejadi dasar pembentuk suatu kesatuan masyarakat hukum adat, secara konseptual hukum adat di sini dapat dimaknai sebagai hukum masyarakat Indonesia asli yang tidak bersumber pada peraturan-peraturan negara, ${ }^{35}$ melainkan hukum yang terbentuk dari adat dan kebiasaan, ${ }^{36}$ yang bersumber dari nilai-nilai masyarakat Indonesia asli, ${ }^{37}$ berbentuk sebagian besar tidak tertulis, ${ }^{38}$ serta memiliki sanksi. ${ }^{39}$

Merujuk pada semua uraian mengenai masyarakat hukum adat di atas, maka secara sosiologis bisa dilihat bahwa keberadaan masyarakathukumadatadalah sebuah bentuk keberagaman struktur sosial yang tercipta sebagai bagian dari keberagaman tradisi masyarakat Indonesia yang beragam dan sekaligus sebagai bentuk ekspresi identitas kultural atas masyarakat yang bersangkutan. Sehingga, berdasarkan prinsip keadilan

\footnotetext{
34 Ter Haar, "loc cit."

35 Van Vollenhoven, sebagaimana dikutip oleh Surojo Wignjodipuro, "Pengantar dan Azas-Azas Hukum Adat," Penerbit Alumni, Bandung, 1979, h. 3.

36 Ibid, h. 2, 4-5. Lihat juga: Moh. Koesnoe, "Hukum Adat sebagai Suatu Model Hukum," Mandar Maju, Bandung, 1992, h. 68-70; Hilman Hadikusuma, "Pengantar Ilmu Hukum Adat," Mandar Maju, Bandung, 1992, h. 17; Bushar Muhammad, "Asas-Asas Hukum Adat. Suatu Pengantar,” Pradnya Paramita, Jakarta, 1975, h. 19.

37 Surojo Wignjodipuro, "op cit," h. 4-5, 7; Moh. Koesnoe, "op cit," h. 69-70.

38 Surojo Wignjodipuro, “op cit," h. 2-3, 5; Moh. Koesnoe, “op cit,” h. 68-70, 72-73.

39 Surojo Wignjodipuro, “op cit,” h. 2, 5.
} 
sosial, keberadaan masyarakat hukum adat beserta segala kekhasan yang ada, termasuk dalam hal hak-hak tradisional, otoritas, dan aturan hukum (adat) yang mereka miliki, merupakan suatu realitas kultural masyarakat Indonesia yang harus diakui dan diakomodasi sepenuhnya menurut prinsip politic of recognition.

Pertanyaannya sekarang adalah, jika merujuk pada kajian hukum secara konservatif dalam tradisi positivisme hukum, bagaimanakah persoalan keberadaan masyarakat hukum adat ini terakomodir dalam kajian tersebut? Sebagaimana yang sudah dijabarkan sebelumnya, kajian hukum dalam tradisi positivisme hukum adalah kajian hukum yang membatasi diri hanya sebatas pada pemaparan atas aturan hukum positif sebagaimana apa adanya. Sehingga, kajian atas eksistensi masyarakat hukum adat hanya bisa dilakukan pada aturan-aturan hukum positif yang menyinggung tentang keberadaan masyarakat hukum adat.

Berdasarkan hal di atas, maka ada beberapa aturan hukum positif yang bisa dijadikan rujukan. Aturan-aturan tersebut antara lain adalah:

Aturan dalam konstitusi, yakni Pasal 18B ayat 2 UUD 1945 yang berbunyi:

"Negara mengakui dan menghormati kesatuan-kesatuan masyarakat hukum adat serta hak-hak tradisionalnya sepanjang masih hidup dan sesuai dengan perkembangan masyarakat dan prinsip Negara Kesatuan Republik Indonesia, yang diatur dalam undangundang."
Berdasarkan ketentuan pasal di atas, maka sepintas terlihat bahwa secara yuridis normatif UUD mengakui dan mengakomodasi keberadaan masyarakat hukum adat. Namun, pasal tersebut menjelaskan bahwa mengenai apa dan bagaimana bentuk pengakuan tersebut haruslah dirujuk pada ketentuan dalam undang-undang, sebagaimana yang dinyatakan dalam frasa ".....yang diatur dalam undang-undang." Oleh karena itu, haruslah dilihat pengaturan-pengaturan yang ada dalam undang-undang untuk mengetahui secara jelas mengenai konsep pengakuan atas masyarakat hukum adat ini.

Sejauh ini, belum ada undang-undang yang secara khusus mengatur tentang eksistensimasyarakathukumadat. Walaupun demikian, telah ada beberapa undangundang yang di dalamnya mengatur tentang keberadaan kelompok masyarakat ini, salah satunya adalah UU No. 5 Tahun 1960 tentang Pokok-Pokok Agraria atau yang dikenal dengan UUPA. Pasal-pasal dalam UUPA yang secara eksplisit menyinggung tentang keberadaan masyarakat hukum adat dan atau yang berhubungan dengannya antara lain adalah Pasal 2 ayat 4, Pasal 3, dan Pasal 5.

Pasal 2 ayat 4 UUPA berbunyi:

"Hak menguasai dari Negara tersebut di atas pelaksanaannya dapat dikuasakan kepada daerah-daerah swatantra dan masyarakat-masyarakat hukum adat, sekedar diperlukan dan tidak bertentangan dengan kepentingan nasional, menurut ketentuan Peraturan Pemerintah." 
Pasal 3 UUPA berbunyi:

"Dengan mengingat ketentuan pasal 1 dan 2, pelaksanaan hak ulayat dan hakhak yang serupa itu dari masyarakatmasyarakat hukum adat, sepanjang menurut kenyataannya masih ada, harus sedemikian rupa sehingga sesuai dengan kepentingan nasional dan negara, yang berdasarkan atas persatuan bangsa serta tidak boleh bertentangan dengan undang-undang dan peraturanperaturan lain yang lebih tinggi." 40

Sedangkan Pasal 5 UUPA adalah pasal yang mengatur mengenai hukum adat, yang berbunyi:

"Hukum agraria yang berlaku atas bumi, air, dan ruang angkasa adalah hukum adat, sepanjang tidak bertentangan dengan kepentingan nasional dan negara, yang berdasarkan atas persatuan bangsa, dengan sosialisme Indonesia, serta dengan peraturan-peraturan yang tercantum dalam undang-undang ini dan dengan peraturan perundangan lainnya, segala sesuatu dengan mengindahkan unsur-unsur yang bersandar pada hukum agama."

Merujuk pada pengaturan tentang masyarakat hukum adat sebagaimana yang ada dalam UUPA di atas, maka jelas terlihat bahwa eksistensi masyarakat adat dan hukum adat diakui hanya jika tidak bertentangan dengan perundang-undangan

40 Pasal 2 (1) UUPA menyebutkan:

"Atas dasar ketentuan dalam Pasal 33 ayat 3 UUD dan hal-hal yang sebagai dimaksud dalam pasal 1, bumi, air, dan ruang angkasa, termasuk kekayaan alam yang terkandung di dalamnya itu pada tingkatan tertinggi dikuasai oleh negara, sebagai organisasi kekuasaan seluruh rakyat." dan kepentingan nasional, di mana mengenai perihal kepentingan nasional ini harus dirujuk pada Pasal 33 ayat 3 UUD 1945 sebagaimana yang disebutkan dalam pasal 3 UUPA, yakni kepentingan penguasaan negara dalam level yang tertinggi atas bumi, air, ruang angkasa beserta segala kekayaan alam yang ada di dalamnya. Sedangkan mengenai dalam Pasal 5 UUPA, dalam penjelasan pasal tersebut yang kemudian merujuk pada penjelasan umum poin III butir (1) disebutkan bahwa yang dimaksud dengan istilah "hukum adat" di sini adalah "hukum adat yang telah disempurnakan dan disesuaikan dengan kepentingan masyarakat dalam negara moderen dan dalam hubungannya dengan dunia internasional, serta disesuaikan dengan sosialisme Indonesia" yakni sekedar bermakna sebagai hukum yang mewujudkan kesadaran masyarakat Indonesia yang berbeda dari hukum perdata barat (yang sudah tidak dipakai lagi). Sehingga, istilah hukum adat yang disebut dalam Pasal 5 UUPA ini bukanlah hukum yang berlaku dalam lingkungan-lingkungan masyarakat hukum adat sebagaimana menjadi makna hukum adat secara tradisional, tetapi merupakan "hukum adat yang sudah dihilangkan sifat kedaerahannya dan diganti dengan sifat nasional." ${ }^{41}$

Apa yang ada dalam pengaturan UUPA di atas hanyalah salah satu dari contoh yang bisa mewakili konsep pengakuan atas keberadaan masyarakat hukum adat dalam berbagai per-UU-an yang ada

${ }^{41}$ Soehardi sebagaimana dikutip Rikardo Simarmata, "op cit," h. 63. 
dalam tata hukum positif Indonesia, yakni konsep pengakuan yang sifatnya terbatas (limited recognition), di mana keberadaan masyarakat hukum adat (berikut hakhaknya) diakui sepanjang tidak bertentangan dengan kepentingan negara dan tidak bertentangan dengan ketentuan perundangundangan. Konsekuensi dari adanya konsep pengakuan sebagaimana demikian adalah bahwa jika ternyata terdapat eksistensi masyarakat hukum adat berikut hak-hak dan kepentingannya yang bertentangan dengan kepentingan negara (kepentingan nasional), ataupun jika ada aturan hukum adat yang bertentangan dengan aturan hukum positif negara dalam perundang-undangan, maka keberadaan masyarakat hukum adat beserta kepentingan-kepentingan dan hak-hak tradisioanalnya yang diatur dalam hukum adat tersebut bisa diabaikan. Jika dikaitkan dengan prinsip keadilan sosial, maka apa yang diatur dalam UUPA sebagaimana dijabarkan di atas cenderung bertentangan dengan prinsip politic of recognition, dan jika kajian hukum hanya didasarkan pada kajian hukum secara konservatif menurut tradisi positivisme ala Kelsenian yang hanya membatasi diri pada aturan hukum positif sebagaimana apa adanya, maka kajian tersebut juga akan menjadi suatu kajian yang isinya akan bertentangan dengan prinsip keadilan sosial.

Di sisi lain, persoalan mengenai tidak terakomodasinya hak-hak kultural masyarakat hukum adat secara maksimal oleh ketentuan dalam hukum positif ini seringkali berujung pada konflik sosial seperti halnya yang sering terjadi di berbagai daerah di Indonesia, di mana konflik ini berakar pada kontradiksi kepentingan di antara masyarakat hukum adat dan negara. ${ }^{42}$ Sehingga, mendasari pada realitas yang seperti ini, maka kajian hukum positif nan positivistik akan benar-benar terasakan a sosial atau begitu terisolir dari permasalahanpermasalahan sosial yang ada hanya karena permasalahan tersebut tidak ada aturan hukumnya atau diatur tetapi tidak sesuai dengan realitas yang ada di masyarakat.

Di sinilah terasa urgensi akan sebuah kajian hukum yang melampaui tradisi positivisme ala Kelsenian. Artinya, demi tuntutan agar kajian hukum tidak hanya sekedar menyinggung prinsip keadilan hukum (legal justice) sebagai keadilan menurut aturan hukum positif yang ada melainkan juga mengakomodir prinsip keadilan sosial, maka kajian hukum tersebut tidak bisa lagi diisolir hanya menyangkut pemaparan atas tata aturan hukum positif yang berlaku semata, tetapi juga harus banyak menyinggung kajian-kajian sosial yang bisa digunakan untuk mendedah realitas struktur sosial yang ada.

Jika dikembalikan pada persoalan eksistensi masyarakat hukum adat, maka

${ }^{42}$ Ulasan mengenai isu ini bisa dibaca di: Joeni Arianto Kurniawan, "Legal Pluralism in Industrialized Indonesia. A Case Study of Land Conflict between Adat People, the Government, and Corporation Regarding to Industrialization in Middle Java," Saarbrücken, VDM Verlag Dr. Müller. Lihat juga: Joeni Arianto Kurniawan, "Mesuji, Land Conflict and Legal Pluralism," Harian The Jakarta Post edisi 22 Desember 2011. Dapat diakses di: http://www.thejakartapost.com/news/2011/12/22/ mesuji-land-conflict-and-legal-pluralism.html 
penggunaan ilmu sosial dalam kajian hukum, atau yang biasa disebut sebagai kajian sosiolegal (socio-legalstudies), akan memberikan hasil yang begitu berbeda dari kajian hukum positif sebagaimana telah dipaparkan di atas. Merujuk pada kajian sosio-legal, maka di dalamnya terdapat studi antropologi hukum sebagai studi yang sangat berkaitan dengan eksistensi masyarakat tradisional, termasuk masyarakat hukum adat, dan dalam studi antropologi hukum ini terdapat suatu pendekatan yang dikenal dengan istilah pendekatan pluralisme hukum.

Secara konseptual, terdapat dua poin penting yang bisa diambil berkait dengan pendekatan pluralism hukum ini, yakni:

Pertama, jika positivisme hukum mengkonsepkan hukum (hanya) sebagai hukum positif dan oleh karenanya mensyaratkan keberadaan lembaga negara sebagai satu-satunya lembaga yang sah yang menciptakan hukum, maka pendekatan pluralisme hukum justru sebaliknya. Hukum dianggap tidak memiliki keterkaitan dengan eksistensi negara, melainkan seperti halnya yang dikonsepkan oleh Eugen Ehrlich yakni pada setiap organisasi sosial dalam bentuk apapun. ${ }^{43} \mathrm{Hal}$ ini didasarkan pada beberapa hal. Pertama, seperti halnya yang diungkapkan oleh Pospisil, pandangan tradisional yang mengkonsepkan hukum hanya sebagai instrumen negara memiliki beberapa persoalan mendasar, yakni bahwa pada faktanya (pernah) terdapat masyarakat yang struktur sosialnya tidak berwujud

\footnotetext{
43 John Griffiths, "What is Legal Pluralism?" Journal of Legal Pluralism and Unofficial Law Number 24, the Foundation for the Journal of Legal Pluralism, 1986, h. 26.
}

dalam bentuk negara yang jika eksistensi hukum hanya dimaknai sebagai hukum negara maka akan membawa kesimpulan bahwa masyarakat tersebut tidak memiliki hukum, ${ }^{44}$ sedangkan pada hakekatnya tidak demikian karena di setiap masyarakat tentu mensyaratkan keteraturan dan setiap keteraturan selalu mensyaratkan adanya aturan (hukum). ${ }^{45}$ Selain itu, jika struktur masyarakat yang ada telah berbentuk negara, maka konsep hukum yang mengidentikkan hukum dengan keberadaan negara akan mengabaikan fakta bahwa sesungguhnya negara bukanlah satu-satunya organisasi yang menerapkan aturan yang menentukan perilaku masyarakat, melainkan masyarakat sesungguhnya berada dalam berbagai lapisan struktur organisasi yang masingmasing memiliki sistem dan tata aturannya sendiri-sendiri yang sama-sama memberikan pengaruh kepada perilaku masyarakat tersebut. ${ }^{46}$

Poin yang kedua adalah bahwa hukum tidak dimaknai secara positivistik nan sempit hanya sebagai hukum positif (hukum negara), melainkan secara luas sebagai berbagai macam aturan internal dalam berbagai macam organisasi sosial. Hal ini didasarkan pada pendapat-pendapat yang dikemukakan oleh para legal anthropologist dan legal sociologist seperti halnya Sally Folk Moore yang berpandangan bahwa ruang sosial antara negara dan seorang

\footnotetext{
${ }^{44}$ Leopold Pospisil, "Anthropology of Law. A Comparative Theory. Hamper and Row Publisher, New York, 1971, h. 99.

${ }^{45}$ Sebagaimana ungkapan Cicero yang terkenal: "Ubi societas ibi ius (Di mana ada masyarakat maka di situ ada hukumnya)."

${ }^{46}$ John Griffiths, "loc cit."
} 
subyek bukanlah sebuah ruang normatif yang vakum, melainkan penuh diisi oleh berbagai institusi sosial dengan aturannya masing-masing, ${ }^{47}$ atau juga pendapat Smith yang menyatakan bahwa kelompok sosial (yang disebut Smith dengan istilah "kooperasi") adalah unit paling mendasar dalam struktur sosial sekaligus sebagai sumber dari setiap tindakan politik, di mana keanggotaan dari seorang individu dalam kelompok sosial itulah yang menjadi sumber utama munculnya hak dan kewajiban yang melekat pada individu tersebut. ${ }^{48}$ Itulah mengapa, Eugen Ehrlich berpendapat bahwa bentuk dasar nan asli dari hukum bukanlah hukum negara, melainkan tatanan internal dari setiap perhubungan atau relasi antar manusia. $^{49}$

Berdasarkan konsep pluralisme hukum sebagaimana di atas, maka jika dibenturkan dengan realitas persoalan keberadaan masyarakat hukum adat dikaitkan dengan otoritas negara dan tata hukum positifnya, maka hasil analisisnya akan menjadi begitu berbeda jika dibandingkan dengan hasil analisis dari kajian hukum positif nan positivistik. Alih-alih melihat masyarakat hukum adat dalam identitas tunggalnya sebagai warga negara yang mutlak harus tunduk pada hukum positif sehingga jikalaupun harus dilakukan pengakuan terhadap keberadaan mereka maka itu hanya sebatas apa yang telah diatur oleh hukum positif semata, maka analisis pluralisme hukum melihat masyarakat hukum adat sebagai suatu entitas sosio-politik yang

\footnotetext{
${ }^{47}$ Sebagaimana dikutip oleh John Griffiths, “ibid,” h. 34.

${ }^{48}$ Ibid, h. 18.

${ }^{49}$ Ibid, h. 25.
}

masih memiliki otoritasnya sendiri walau telah berada di bawah naungan otoritas negara sehingga mereka juga dipastikan memiliki aturan hukumnya sendiri, yakni hukum adat, yang turut atau bahkan paling berpengaruh terhadap pola perilaku masyarakat tersebut. Berdasarkan analisis sebagaimana demikian, maka aturan hukum positif negara yang dalam hal ini kurang memberikan akomodasi dan pengakuan atas keberadaan masyarakat hukum adat bukan lagi satu-satunya aturan hukum nan superior dan oleh karenanya secara teori menjadi mutlak berlaku, melainkan suatu aturan hukum yang harus dikontestasikan dengan aturan hukum yang lain yakni hukum adat dari kesatuan masyarakat hukum adat yang bersangkutan yang justru pada faktanya lebih berpengaruh pada pola perilaku masyarakat tersebut. Jika keadaan seperti ini yang dijadikan acuan, maka urgensi pengakuan atas masyarakat hukum adat akan jauh lebih terasa mengingat dalam suatu medan kontestasi, jika suatu aturan hendak memberikan suatu nilai keberlakuan (baca: diterima) dalam suatu entitas masyarakat maka aturan hukum tersebut juga harus menyesuaikan diri dengan aturan hukum lain, yang menjadi lawan kontestasinya, yang juga berlaku dan ditaati oleh masyarakat yang bersangkutan.

\section{Penutup}

Dalam kajian hukum, isu keberlakuan hukum adalah isu yang penting untuk ditelaah karenabagaimanapunhukumadalah sebuah instrumen praktis yang hanya akan memiliki nilai jika ia bisa bekerja memenuhi 
fungsinya, atau dengan kata lain dapat efektif berlaku di masyarakat. Mengingat bahwa hukum diterapkan pada masyarakat, maka bagaimana kondisi struktural masyarakat tersebut akan sangat menentukan bagaimana hukum tersebut bekerja di masyarakat yang bersangkutan. Dari sini maka sesungguhnya dapatlah terlihat bahwa guna mencapai keadilan hukum (berlakunya suatu hukum sesuai dengan rumusan normatifnya) maka dibutuhkan adanya keadilan sosial, sehingga walaupun keadilan hukum dan keadilan sosial adalah dua konsep yang berbeda, namun kedua konsep keadilan tersebut saling mempengaruhi.

Berdasarkan hal tersebut, maka kajian hukum yang tidak menjangkau permasalahan keadilan sosial sesungguhnya tidaklah dapat dipertahankan lagi. Sebaliknya, kajian hukum haruslah membuka spektrumnya untuk juga memasukkan kajian-kajian sosial yang relevan guna mengembangkan kajian hukum tersebut karena dari kajian-kajian sosial inilah permasalahan-permasalahan yang ada dalam isu keadilan sosial dapat terdedah, dan untuk tujuan inilah kajian sosio-legal dimunculkan, untuk terus ditumbuh kembangkan guna terciptanya suatu kajian hukum yang berkeadilan sosial. Analisis pluralisme hukum, sebagai suatu pendekatan yang ada dalam kajian sosiolegal, adalah suatu teori analisis yang bisa digunakan untuk mendedah struktur sosial masyarakat dalam hal kompleksitas lembaga sosial yang hidup dalam tatanan masyarakat tersebut, sehingga negara beserta hukum positifnya bukan lagi satu-satunya lembaga sosial nan ekslusif dalam masyarakat dan oleh karenanya dorongan untuk mengakomodir dan mengakui keberagaman masyarakat (yang hidup dalam kompleksitas dan keberagaman lembaga-lembaga sosial tersebut) dapat lebih teraktualisasikan.

\section{Daftar Bacaan}

Bushar Muhammad, "Asas-Asas Hukum Adat. Suatu Pengantar," Pradnya Paramita, Jakarta, 1975.

David Boucher and Paul Kelly, "Social Justice. From Hume to Walzer," Routledge, London-New York, 1998.

Fakultas Hukum Universitas Indonesia, "Sejarah Singkat Fakultas Hukum UI," tersedia di: http://law.ui.ac.id/ index.php?option=com content \&vie $\underline{\mathrm{w}=\text { article } \& \mathrm{id}=46 \& \text { Itemid }=55}$

Hans Kelsen, "Pure Theory of Law," The Lawbook Exchange, Clark-New Jersey, 2005.

Harun Hadiwijoyo, "Seri Sejarah Filsafat Barat 2," Kanisius, Yogyakarta, 1990.

Hilman Hadikusuma, "Pengantar Ilmu Hukum Adat," Mandar Maju, Bandung, 1992.

James G. Apple \& Robert P. Deyling, "A Primer on the Civil Law System," Federal Juducial Center of the United States, tanpa tahun.

Joeni Arianto Kurniawan, "LegalPluralismin Industrialized Indonesia. A Case Study of Land Conflict between Adat People, the Government, and Corporation Regarding to Industrialization in Middle Java," VDM Verlag Dr. Müller, Saarbrücken. , "Mesuji, Land Conflict and Legal Pluralism," Harian The 
Jakarta Post edisi 22 Desember 2011. Dapat diakses di: http://www. thejakartapost.com/news/2011/12/22/ mesuji-land-conflict-and-legalpluralism.html.

John Griffiths, "What is Legal Pluralism?" Journal of Legal Pluralism and Unofficial Law Number 24, the Foundation for the Journal of Legal Pluralism, 1986.

Kompas, "Kejamnya Keadilan 'Sandal Jepit', Edisi 6 Januari 2012, tersedia di: http://nasional.kompas. com/read/2012/01/06/09445281/ Kejamnya.Keadilan.Sandal.Jepit.

Leopold Pospisil, "Anthropology of Law. A Comparative Theory. Hamper and Row Publisher, New York, 1971.

Lili Rasjidi dan Ira Thania Rasjini, "DasarDasar Filsafat dan Teori Hukum," Citra Aditya Bakti, Bandung, 2004.

Moh. Koesnoe, "Hukum Adat sebagai Suatu Model Hukum," Mandar Maju, Bandung, 1992.

Nancy Fraser, "Social Justice in the Age of Identity Politics: Redistribution, Recognition, and Participation" dalam Nancy Fraser dan Axel Honneth, "Redistribution or Recognition? A Political-Philosophical Exchange", Verso, London-New York, 2003.
Rikardo Simarmata, "Pengakuan Hukum terhadap Masyarakat Adat di Indonesia," Regional Initiative on Indigenous Peoples' Rights and Development, UNDP, Jakarta, 2006.

Soehino, "Ilmu Negara," Penerbit Liberty, Yogyakarta, 1993.

Surojo Wignjodipuro, "Pengantar dan AzasAzas Hukum Adat," Penerbit Alumni, Bandung, 1979.

Soetandyo Wignjosoebroto, "Dari Hukum Kolonial ke Hukum Nasional. Dinamika Sosio-Politik dalam Perkembangan Hukum di Indonesia,". Raja Grafindo Persada. Jakarta, 1994. Metode, dan Dinamika Masalahnya," Elsam-Huma, Jakarta, 2002.

Ter Haar, "Asas-Asas dan Susunan Hukum Adat," Pradnya Paramita, Jakarta, 1979. 